\title{
ERŐFORRÁS VAGY VESZÉLYFORRÁS? \\ AZ AKNASZLATINAI (SOLOTVYNO) SÓBÁNYÁK MÚLTJA, JELENE ÉS JÖVŐJE
} GEORESOURCE OR GEOHAZARD? PAST, PRESENT AND FUTURE OF THE SALT MINES IN SOLOTVYNO

\author{
MÓGA JÁNOSad - GÖNCZY SÁNDOR ${ }^{\text {be }}$ - BERGHAUER SÁNDOR ${ }^{\text {bf }}$ - MÓGA \\ KRISTÓFg \\ ${ }^{a}$ ELTE TTK FFI Természetföldrajzi Tanszék, ${ }^{b}$ II. Rákóczi Ferenc Kárpátaljai Magyar Főiskola, Földrajz tanszék, \\ Beregszász, ${ }^{\mathrm{c}}$ Nemzeti Közszolgálati Egyetem

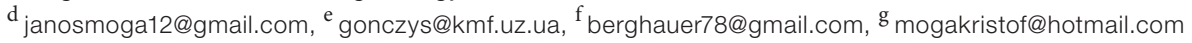

\begin{abstract}
Rock salt is one of the most valuable mineral raw material of the Carpathians and the Carpathian basin that has been mined for thousands of years in the Transylvanian and Maramureş basin, as well as in Solotvyno (Aknaszlatina). Rock salt, folded into saltdiapirs - often reaching the surface, or being very close to it, - has been possible to be excavated from open-cast or underground mines. The industrial-scale salt mining in the Carpathian basin started in the late 18th century. In Solotvyno in the first decade of the 21st century a large amount of water poured into the mine passages, since the pumping of which costed too much the management of the mines. Water intrusions caused massive damage in salt mines, often resulting in flooding and later the collapse of salt shafts. Mine passages slumped more frequently, creating larger and smaller sinkholes and salt lakes, evolving in the place of cave breakdowns and endangering the settlement. As a consequence, many people lost livelihood. It is an important task for researchers and decision makers to find a way out of this disaster.
\end{abstract}

Keywords: Solotvyno saltmines, collapses, geohazard, saltkarst, sinkholes, damage management

\section{A só a Föld egyik éltető eleme}

A kősó a Kárpátok és a Kárpát-medence egyik legértékesebb ásványi nyersanyaga, amelyet évezredek óta bányásznak az Erdélyi- és a Máramarosi-medencében, valamint a Keleti-Kárpátokban (Schmidt Eligius R. 1941, Hahn Gy. 1993, Izsák T. 2007, Rе́тнy K. 2010, 1. ábra). A só a Föld egyik éltető eleme. Megtalálható a tengerben, a szárazföldön és az élőlényekben is. A vérünk vagy a magzatvíz sótartalma hasonló az óceánok átlagos sótartalmához. A só nemcsak az ember, hanem minden élőlény számára létfontosságú természetes, szervetlen anyag. Az életfolyamatok normális müködéséhez a sók nélkülözhetetlenek, ezek szabályozzák együttesen a szervezet vízháztartását. Ha ezek aránya nem megfelelö, akkor az élőlények megbetegednek és elpusztulnak. 
A történelmi időkben a társadalom mindenkori sóigényének kb. 75\%-a táplálkozási, hús- és ételtartósítási tömegigényeket elégített ki. A termelés 25\%-át házi állatok, $40 \%$-át közvetlenül az emberek fogyasztották, a maradék 35\%-át pedig a konzerváló eljárásoknál (elsősorban a húsénál) közvetve hasznosították. A számítások szerint egy felnőtt ember napi sóvesztesége az éghajlattól függően 3-8 g/nap/fö. A szervezet víz- és sókoncentrációja a kiválasztás és verejtékezés során az állatvilágban is csökken, amit a ragadozó állatok az elfogyasztott állat véréből pótolnak. A növényevők a sóhiány kiegyenlítésére sós növényekkel táplálkoznak vagy rendszeresen sótartalmú anyagokat nyalnak. A háziállatok sóigényének kielégítéséről azonban az ember gondoskodik a só táplálékhoz történő adagolásával. Mindezen igények kielégítésére mindenkor nagy mennyiségü só kitermelésére volt szükség, amelyet tengervízből történő sólepárlással vagy sóbányászattal oldottak meg (HaHn Gy. 1993).

A sókitermelés lényegében egyidős az emberi társadalommal. Az állattenyésztő és földművelő életforma elterjedésével a háziállatok sószükségletének kielégítése miatt megnőtt a só iránti kereslet. A kősó kinyerésének legkezdetlegesebb formái a Kárpátmedencében a sós források vizének ember és (tenyésztett) állat által történő felhasználásával kezdődtek. Az erdélyi és a máramarosi sóbányák térségében a neolitikumi és bronzkori kezdetleges sófejtés nyomait több helyen is megtalálták a régészek. A kitermelt nagy sómennyiség arra is utal, hogy abban az időben jelentős cserekereskedelem létezhetett a területen. A sótermelés nyilvánvalóan a felszínre bukkanó sósziklákon kezdődött, de annak kimerülésével a kőkor embere a lelőhelyet a felszín alatt tovább fejtette. A római korból származó mélyművelések nyomai Máramarosban is fellelhetők (HAHn Gy. 1993).

A római kori kősókitermelés folytonossága a népvándorlás idején Erdélyben és Máramarosban megszakadt, illetve lehanyatlott, és csak a magyar honfoglalás és államalapítás utáni időkben történt fellendülés. A Máramarosi-medence egyik legfontosabb nyersanyaga, erőforrása a mintegy $1500 \mathrm{~km}^{2}$ területre kiterjedő só, amely legtöbb helyen fedöüledékek alatt rejtőzködik, csak néhány helyen közelíti meg a felszínt, illetve bukkan felszínre. A sórétegek a miocén badeni korszakában a Középső-Paratethys tenger medencéjében a sós tengervíz bepárlódásával rakódtak le. A későbbi tektonikai mozgások a kősót sódómokká (sódiapír) gyűrték és számos helyen felszínre vagy felszín közelbe emelték. A legfontosabb máramarosi sólelőhelyek évszádok óta Aknaszlatina (Solotvyno, ma Ukrajna), Rónaszék (Coştiui, ma Románia) és Aknasugatag (Ocna Şugatag, ma Románia). 


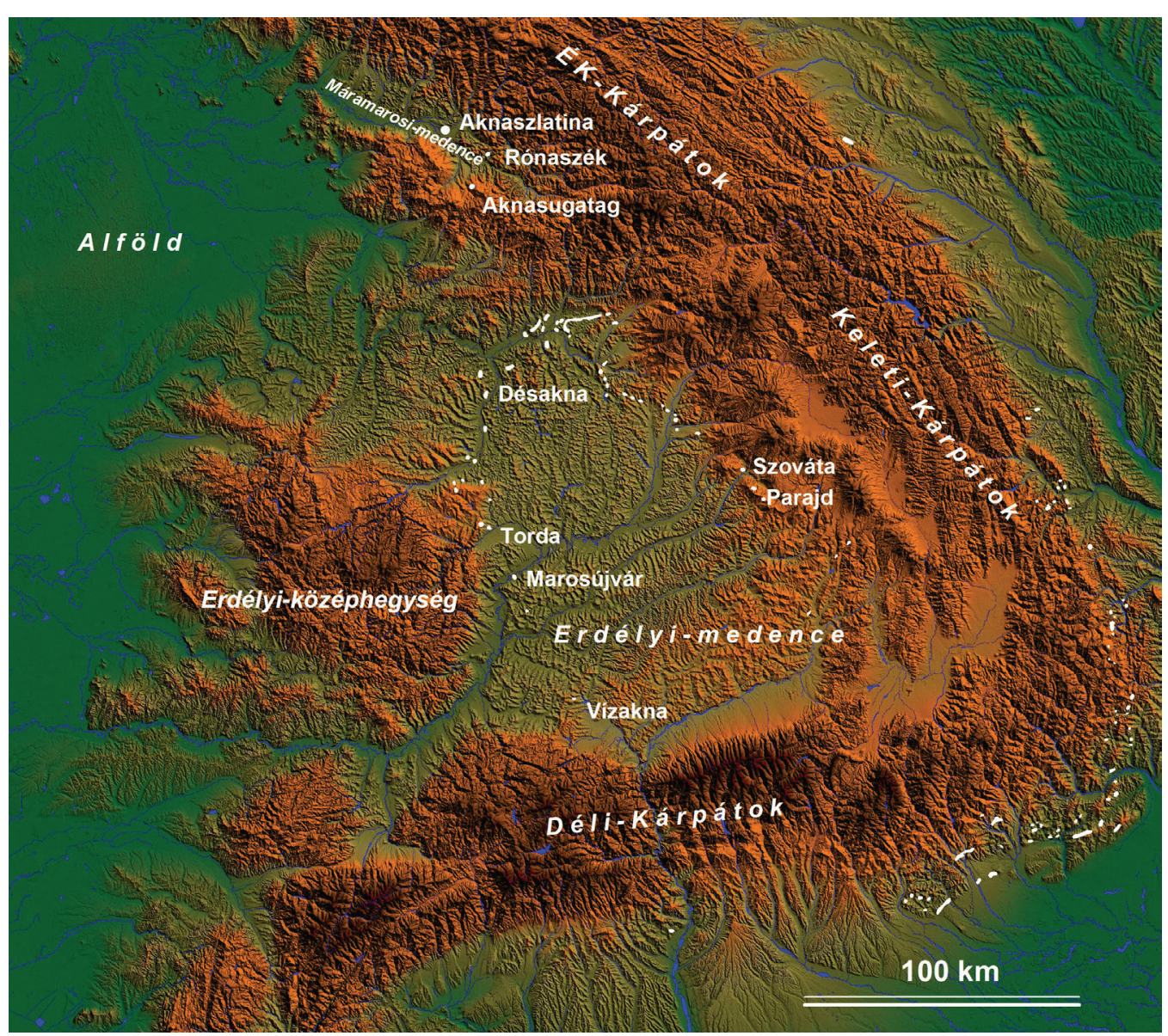

1. ábra. A Kárpátok és a Kárpát-medence legfontosabb sódómjai és sóbányái (szerk. Móga J.)

\section{A sóbányászat technológiájának változása}

A rónaszéki sóbányászat eredete a legrégibb időkre vezethető vissza. Oklevelek tanúsítják, hogy az ottani sóbányák Ulászló király uralkodása alatt a 15. században már művelés alatt álltak. Nagyobb szabású bányaművelés 1674-es évben vette kezdetét. Aknasugatag az 1325-ös év óta jelentős sókitermelö-helyként számon tartott település. Aknaszlatinán az első bányát valószínűleg a 13. század elején nyitották meg. IV. Béla leánya, Kinga (vagy más néven Kunigunda) 1239-ben Boleszláv lengyel királyhoz ment férjhez, és egy Aknaszlatinán és a lengyelországi Wieliczkán fennmaradt legenda szerint nászajándékul a király leányának ajándékozta a máramarosi sóbányákat. A királynő Lengyelország felé 
menve, útját megszakítva látogatta meg a szlatinai sóbányát. A Kunigunda-bánya neve állítólag e látogatás emlékét őrzi (LuKÁcs K. - LukÁcs J. 1999)

A legrégibb időkben csak külszíni fejtéssel termelték a sót, a sókibúvások anyagát fejtették, később pedig ácsolattal védett aknák segítségével jutottak el a sótesthez. A bányák vízbetörés elleni védelmét gondosan megtervezték, ami egyrészt a felszíni vizek elleni szigetelést, másrészt a beszivárgó vizek elvezetését jelentette. A bejárati aknát pár méterrel a tiszta sóban még tovább mélyítették, majd harang alakúan kiszélesítették. A sótestbe mélyített harang vagy csúcsíves boltozatok kör vagy ellipszis szelvényűek voltak, átméröjük több tíz méter volt, mélységük pedig akár a 150 métert is elérte. A kitermelt sótömbök szállítása lójárgánnyal történt, amit a szállítóaknában alakítottak ki. A darabos sót kenderkötélből készült hálókban emelték a felszínre. A sóbányászok az ún. járóaknában szabadon felfüggesztett kötélhágcsón közlekedtek (SCHMIDT Eligius R. 1941, RÉTHY K. 2010, 2. ábra).

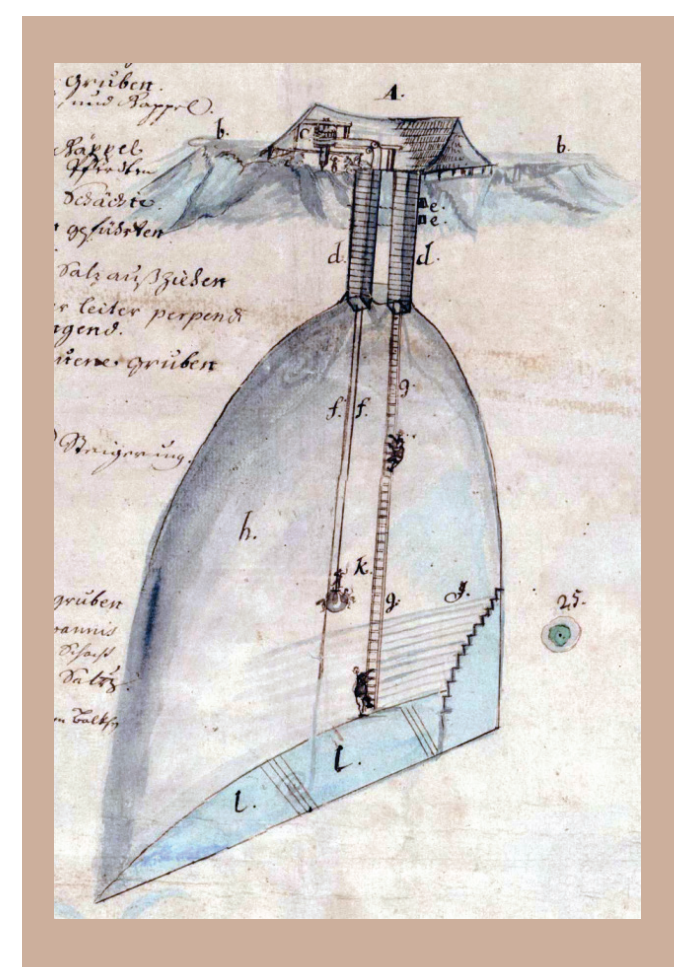

2. ábra. A 18. század végéig harang alakú bányákban történt a sóbányászat. Egy rónaszéki bánya metszete a szállitó- és járóaknával. (Részlet Großschmidt, Johann Xtoph 1743-ban a rónaszéki bányákról készült térképéből) 
A 18. század második feléig kizárólag ilyen harang alakú bányákban fejtették a sót Magyarországon, ezt követően azonban bevezették a wieliczkai bányáknál akkortájt már sikerrel alkalmazott kamrás müvelést. A kamrafejtésnél a szállító tárnából vágatokat hajtanak, amelyeket bizonyos távolságokban keresztkamrákkal kötnek össze, a kamrák között pedig biztonsági pilléreket hagynak meg (SCHMIDT ELIGIUs R. 1941, RÉтнy K. 2010). A só fejtése a kamra talpán, felülről lefelé haladva történik. A kamrák szelvénye trapéz alakú. A kamrafolyosó (galéria) szélessége 10-15 m. A folyosók alatt a falak $45-60^{\circ}$-os szöggel vannak kiképezve, amelyek azután függőlegesbe mennek át. Statikai szempontok figyelembevételével a kamrák talpszélessége általában 30-40 m. A kamrák felső részén folyosó fut végig, ami a mennyezet ellenőrzését teszi lehetővé. Mindezeket a máramarosi bányákban napjainkban már nem láthatjuk, valamennyi sóbánya vízbetörés áldozata lett. Ha valaki ezt a hagyományos aknás-kamrás fejtési módot szeretné megismerni a Kárpát-medencében, akkor a gyönyörűen felújított erdélyi Tordai-sóbányába kell ellátogatnia.

\section{A sóbányák mint erőforrások}

A magyar államalapítás után a királyság fontos feladata volt a védelmi rendszer (kezdetben gyepürendszer), valamint a közigazgatási hálózat (vármegyék) kiépítése és müködtetése mellett az egyházi szervezet (püspökségek és egyházközségek) létrehozása és anyagi javakkal történő ellátása. Ebben nagy szerepet játszottak az ún. regálék, azaz a királyi felségjogon szedett, az államkincstárt illető jövedelmek, amelyek egyik fö forrása a fizetőeszközként is szolgáló kősó volt. Az első fontosabb, a kősóhoz kapcsolódó adománylevelek a 11-12. század fordulójáról maradtak meg, ilyen adományokban elsősorban a termelési helyek környéke, a szállítási útvonal melletti települések és az államhatalom támaszául is szolgáló egyházi intézmények, szerzetesrendek részesültek. A kősó monopóliumából származó haszon a középkor erős királyai alatt a királyi vagy állami jövedelem 10-15\%-át adta. A kősó jelentőségét mutatja, hogy 1222-ben az Aranybulla, majd a II. András és az egyház között kötött 1233. évi beregi egyezmény is megemlékezik róla. Az Árpád-házi királyok idejében még főleg az erdélyi sóbányák szolgáltatták a szükséges sót, a gyepüre eső máramarosi sólelőhelyek csak a tatárjárás utáni országfejlesztő időszakban, valamint külföldi munkaerő beáramlása, a terület betelepítése után értékelődtek fel (Hahn Gy. 1993, F. RomнÁnyi B. 2016). Máramarosban és Técső környékén a 13-14. században, a gyepük megszűntével indult meg a sóbányászat. A só szállítása ekkor még a helyi királyi várispánok hatáskörébe tartozott, majd később a sókamarákhoz, amelynek rendszerét Nagy Lajos király uralkodása alatt alakították ki. 
A kamarák - amelyek között már a máramarosi is szerepelt - biztosították az ország egész lakosságának egyenletes és biztonságos kősóellátását. A sóbányák túlnyomó része királyi birtok maradt évszázadokon át. Még a 15. században, V. László uralkodása alatt is az összes királyi bevétel 40\%-át adva a kősó számított a fő kincstári jövedelemnek (HAHN Gy. 1993).

\section{Az aknaszlatinai sóbányák}

A Máramarosi-medencében, a ma Romániához tartozó Máramarosszigettől (Sighetu Marmației) északra a Tisza völgyében, de már Ukrajna területén egy kavicsterasz alatt fekszik a mintegy $1,9 \mathrm{~km} 2$ kiterjedésü, körte alakú aknaszlatinai sódóm. A Tisza dél felöl széles kanyarral megkerüli ezt a felemelkedő sódómot (sódiapírt), amelynek hosszabb tengelye körülbelül $2400 \mathrm{~m}$, legnagyobb szélessége körülbelül $1300 \mathrm{~m}$, a mélysége pedig több mint $600 \mathrm{~m}$ (3. ábra). A sódóm eltemetett helyzetben van, átlagosan 25-30 m vastagságban kaviccsal, homokkal és néhány méter vastag vízálló sóagyaggal (pallaggal) fedve (Szokol P. 1879, Cholnoky J. et al. 1926, Schmidt Eligius R. 1941, Réthy K. 2010).

A korszerü sóbányászat a 18-19. század fordulóján kezdődött Máramarosban, legfontosabb helyszínei Rónaszék, Aknasugatag és Aknaszlatina voltak. A bányák kincstári tulajdonban voltak, azokat tisztjei vezetésével a kamara művelte, a só termelése és kereskedelme pedig kincstári monopóliumnak számított. Az intenzív sóbányászatnak köszönhetően az 1860-as években a magyarországi termelésnek több mint 50\%-a került ki a máramarosi bányákból, ezen belül az aknaszlatinai sóbányák az országos kitermelés 23\%-át adták. 1880 után a bányaigazgatóság Aknaszlatinán működött, és mind Rónaszéket, mind Aknasugatagot annak rendelték alá.

Aknaszlatinán az ipari méretű sóbányászat 1778-ban kezdődött. Összesen 10 sóbányát nyitottak meg (4. ábra), abból kilencben termeltek; napjainkra azonban egy sem maradt meg, mindegyik vízbetörés áldozatául esett. Az alábbiakban olvasható a sóbányák neve a bányák megnyitásának és pusztulásának időpontjával, valamint néhány rájuk jellemző tényező megemlítésével:

1. Krisztina bánya (1778-1780?);

2. Albert akna (1781-1788);

3. Kunigunda-bánya (1789-1906 vízbetörés);

4. Miklós bánya (1789-1790-ben egyesült a Kunigunda-bányával);

5. József-bánya (1804, tartalékbányának használták); 


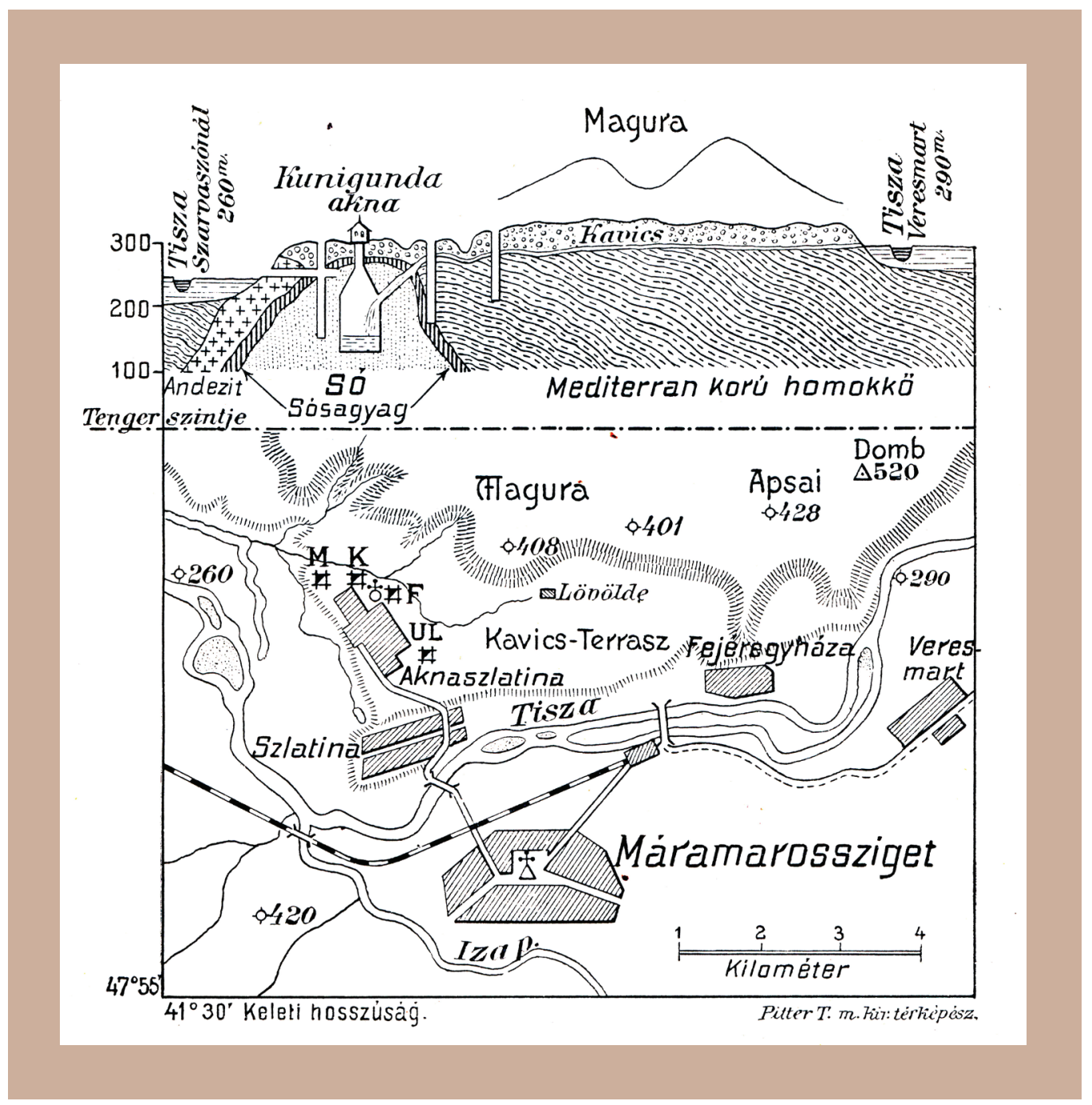

3. ábra. Az aknaszlatinai sóbányák helyszinrajza és a Kunigunda-bánya földtani szelvénye (forrás: Cholnoky J. et al. 1926. p. 79.)

6. Lajos-bánya (1804-1809, befulladt);

7. Ferenc-bánya (1808-1950-es évek?);

8. Új-Lajos-bánya (1886-2010);

9. Kilences-bánya (1975-2010, benne asztma- és allergiagyógyító szanatóriumot hoztak létre 1976-ban);

10. Tízes-bánya (a szovjet időkben lett kész, de sohasem használták termelésre). 


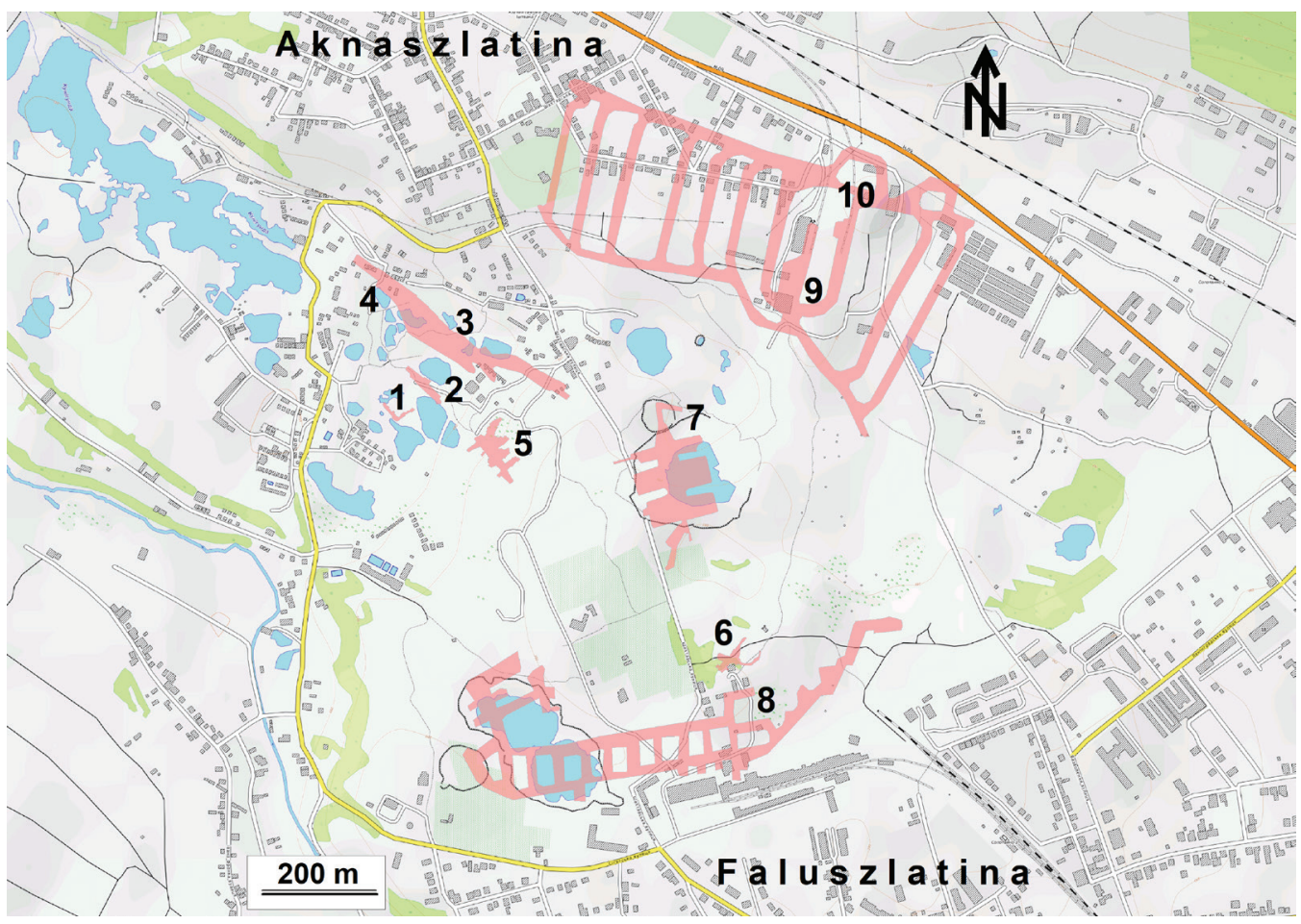

4. ábra. Az aknaszlatinai sóbányák: 1. Krisztina-, 2. Albert-, 3. Kunigunda-, 4. Miklós-, 5. József-, 6. Lajos-, 7. Ferenc-, 8. Új-Lajos-, 9. Kilences-, 10. Tízes-bánya (Open Topo Map alapján szerk. Móga J.)

Aknaszlatinán a sóbányászat mellett, ahhoz kapcsolódóan az utóbbi évtizedekben a gyógyturizmus is kialakult, amely sokak gyógyulását szolgálta, munkahelyeket teremtett a településen és jelentős bevételhez juttatta a lakosságot. A sóbányák sóionokkal telített levegője, állandó hőmérséklete és páratartalma, baktérium- és sugárzásmentes közege a légúti és allergiás betegségek gyógyítására kiválóan alkalmas. Ezt felismerve 1968-ban kialakították a légúti megbetegedések kezelését ellátó Ukrajnai Allergológiai Kórházat és a Kárpátaljai Megyei Allergológiai Kórházat, ahol egyszerre 240 beteg gyógyítását végezték. A kezelést a 8-as és a 9-es bányában végezték, utóbbiban 300-320 méter mélyen kórtermet és még kápolnát is kialakítottak, amelyet 2010 előtt a látogatók is felkereshették (BERGHAUER S. 2012, 5. ábra). A bányabeomlások révén kialakult sóstavakban is kialakult a gyógyturizmus egy formája, balneológiai célra hasznosították azokat az 1970-es évektől kezdve. Nagyobb fellendülés Ukrajna függetlenné válása és a rendszerváltás után történt, amikor a környék lakói körében látogatottá váltak a 146-200 g/l sótartalommal rendelkező sóstavak. Népszerüségüket annak köszönhették, 


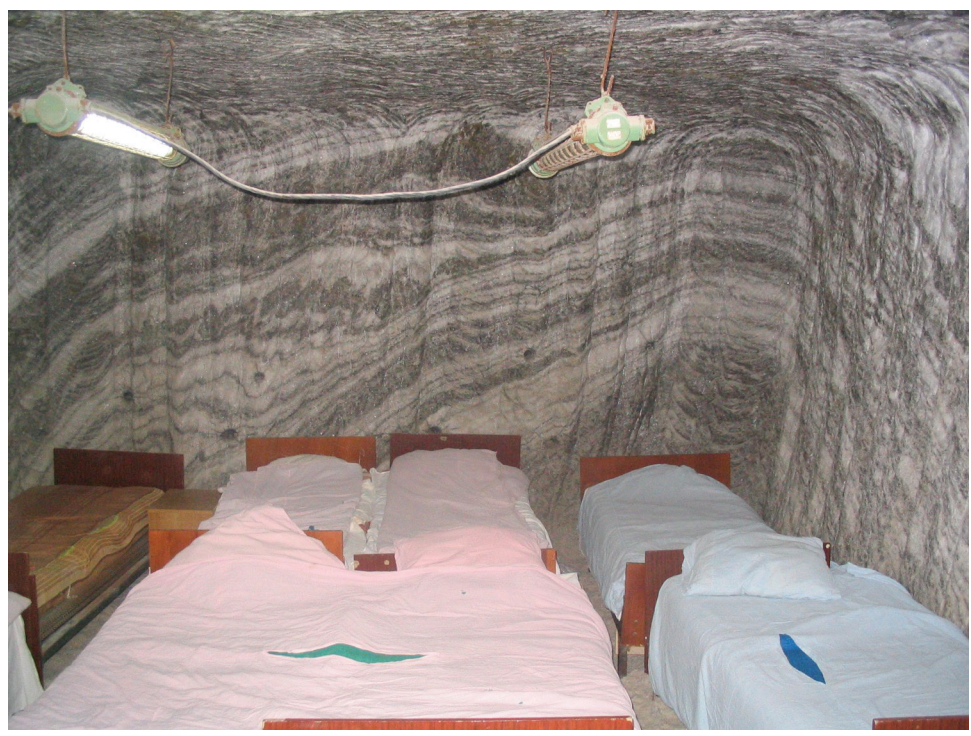

5. ábra. A 9-es bányában 320 m mélyen alakitották ki a sóterápia számára a kórtermet, ami később vizbetörés áldozatául esett (fotó Móga J.)

hogy széles körben elterjedt a híre annak, miszerint gyógyászati szempontból a tavak vize a Holt-tengeréhez hasonló. A tómedencében kialakult iszapot is használták gyógyászati célokra. A sóstavakra kiépült idegenforgalom 2002-2008 között érte el tetőpontját, amikor évente mintegy 100000 vendég érkezett Aknaszlatinára fürödni, gyógyulni. A nyári idegenforgalmi szezonban a település lakosságának száma az oda érkező turisták miatt megduplázódott. Egy nagy kiterjedésű, de festői rendezetlenséggel jellemezhető üdülötelep alakult ki a tavak körzetében (Berghauer S. 2012). Ezt a paradicsomi állapotot és az idegenforgalom dinamikus növekedését az Ukrajna és Oroszország között kibontakozott háborús konfliktus erösen visszavetette.

\section{A sóbányák mint veszélyforrások}

A sóbányák legnagyobb ellensége az édesvíz, ami gyorsan oldja a kőzetet és ez által statikai gondokat okoz. A sóbányák aknáit gyakran a völgyek talpára telepítették, mert a só itt volt mindig a legkönnyebben elérhető. Ez azonban rendkívüli veszélyt jelent a sóbányászatra. Ahol az édesvíz eléri a sódómot, ott az oldás következtében csakhamar üregesedés indul meg, felszín alatti vízjáratok keletkeznek, ami előbb-utóbb végzetes hatással jár: a víz a bányaüregekbe betörve oldja és alámossa a pilléreket, az oldalfalakat, úgyhogy végül is a bánya beszakad, a víz elönti. A vízbetörések hatalmas 
károkat okoztak, gyakran a sóaknák „befulladását”, majd az aknák beomlását okozták. Aknaszlatina, Vízakna, Aknasugatag, Marosújvár környékén (1. ábra) több tucat szakadéktöbör és sóstó jelzi az egykori beomlott bányák helyét.

Az első részletesen dokumentált bányapusztulás az aknaszlatinai Kunigunda-bánya esete. A csapadékvíz - és magas vízálláskor a Tisza vize - a helyenként 30 méternél vastagabb kavicsteraszokon át a sótest fölé jut. Keletre, Veresmartnál, a kanyar elején a Tisza vízállása körülbelül $30 \mathrm{~m}$-rel magasabb, mint a körülbelül $12 \mathrm{~km}$-rel nyugatabbra, a kanyar végében fekvő Szarvasszónál. Ezért a Tiszának a nyugat felé lejtő kavicsba jutott vize kelet-nyugati irányban áramlik. Közben áthalad a sódómon, és ott, ahol a védőréteg - a homokos, márgás, sós agyag - hiányzik vagy elvékonyodik, megtámadja a gyorsan oldódó sót. Ezért fulladtak el a Kunigunda és a vele közvetlenül szomszédos bányák is 1906-ban (SснміDт Eligius R. 1941) (3. és 4. ábra). A beomlások és részben a bányaművelés okozta talajsüppedések miatt Aknaszlatina lakóházait a két világháború között északabbra telepítették át. A katasztrófát következő években a sódómtól keletre, a kavicstelep és a vízzáró pallag határán több felszín alatti vízelvezető csatornát alakítottak ki, amelyek a veszélyes vizeket összegyüjtötték, még mielőtt azok a sótömzsben kárt tehettek volna. Ezek évtizedeken át több-kevesebb eredménnyel védték a bányákat. A Szovjetunió összeomlása körüli időkben azonban az említett felszín alatti, valamint a felszíni vizek elvezetésére kialakított csatorna- és tárnarendszer, az úgynevezett stólok karbantartására egyre kevesebb figyelmet fordítottak, ezért egyre több víz szivároghatott le a sótömbbe és a bányákba is egyre nagyobb mennyiségben nyomult be a felszíni víz, amelynek a kiszivattyúzása túl nagy költségekkel járt. Emiatt - és egy tiszai árvíz vízbetörése következtében - 2010 végére az utolsó két működő sóbánya (az Új-Lajosbánya és a Kilences-bánya) is elfulladt és beomlott. Mindez nemcsak hogy lehetetlenné tette a további bányamüvelést, hanem a bányavágatok mennyezetének felszínig hatoló beomlásával, a felszínen kialakuló kisebb-nagyobb gödrökkel, szakadékokkal, a beszakadások helyén létrejött víznyelőkkel és sós tavakkal napjainkban súlyosan veszélyezteti a település lakóházait is (Bergh AUER S. 2012, MóGA J. et al. 2015).

\section{Sókarsztos felszínformák kialakulása}

A só oldódása alapvetően eltér a mészkőkarsztok karbonátos és hidrokarbonátos oldási folyamataitól, sokkal egyszerübb folyamat azoknál. Az oldás semleges $\mathrm{pH}$ mellett is végbemegy, a kősó $(\mathrm{NaCl}) \mathrm{Na}$ és $\mathrm{Cl}$ ionokra esik szét. Éppen ezért ezt a folyamatot parakarsztos oldódásnak, az így kialakult karsztot parakarsztnak nevezzük. Az idő szerepe 
is más, laboratóriumi kísérletek kimutatták, hogy a kősó desztillált vízben több mint 25 000-szer gyorsabban oldódik, mint a mészkő (JAKUCs L. 1971).

$\mathrm{Az}$ aknaszlatinai sódiapír eredetileg minden bizonnyal fedett volt. Az évszázadok óta tartó, részben felszínen végzett, részben mélyművelésű sóbányászat következtében a fedőüledékek egyes helyeken történő lepusztulásával és ez által a só felszínre kerülésével kisebb foltokban a csapadékvíz oldó hatására nyílt karszt keletkezett. A vízzáró réteg megbolygatásával a felszínről beszivárgó és a kavicsban áramló vizek érintkezésbe kerültek a só felszínével, ahol megindult a korrózió. A felszíni berogyások (horpák, szakadéktöbrök) kialakulása és a sóaknák beomlása minden esetben oldás nyomán létrejött anyaghiányra vezethető vissza. Az aknaszlatinai sókarszt formakincse a természetes úton is lejátszódó parakarsztos folyamatok, a természetes úton is lejátszódó, ám az emberi tevékenység hatására rendkívüli mértékben felgyorsuló („természeti-antropogén”), valamint az emberi beavatkozásra akaratlanul elinduló, de végül öntörvényűen fejlődő („szemiantropogén”) folyamatok eredményeként alakult ki (ERDősi F. 1969, 1987, Horváth G. et al. 2006). A sókarszt legnagyobb méretü szakadéktöbrei a bányakamrák beomlásával alakultak ki. A beomlás rendkívül gyorsan, néha napok vagy hetek alatt ment végbe. A római Colosseum méretét elérő, ill. azt meghaladó, kb. 180-230 m átméröjü és mintegy 30-40 m mély szakadéktöbrök a sókarszt legnagyobb méretű formái (6. és 7. ábra).

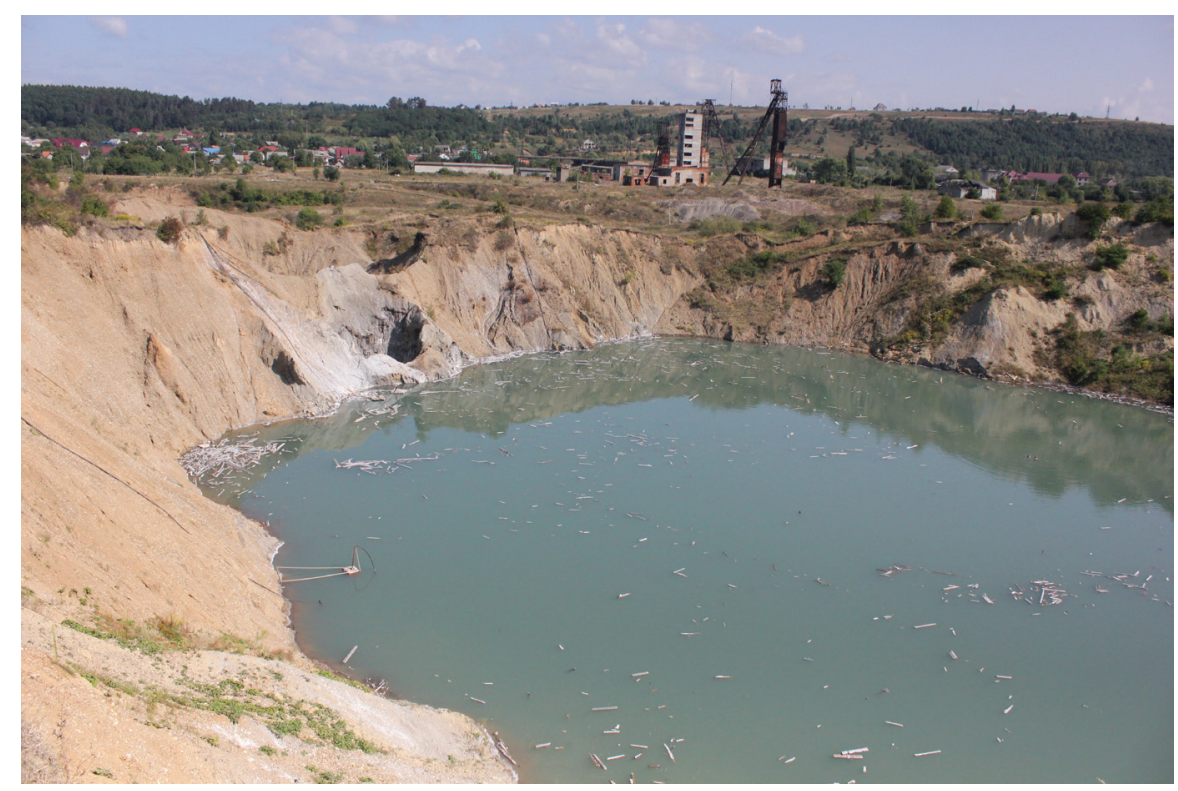

6. ábra. A Ferenc-bánya felett kialakult szakadéktöbör (fotó: Móga J.) 


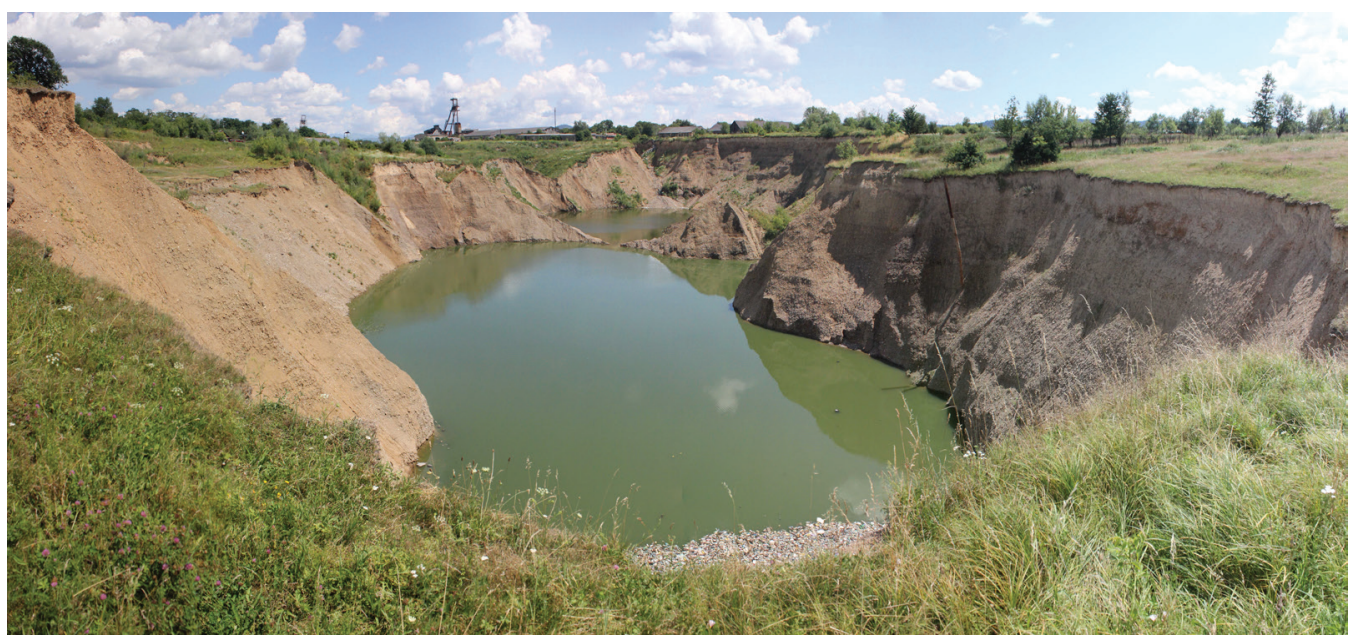

7. ábra. Az Új-Lajos-bánya helyén kialakult Nagy-szakadéktöbör (fotó: Móga J.)

Nyílt karsztos térszínek, csupasz sókőzeten kialakult karrmezők lényegében csak a legnagyobb méretű szakadéktöbrök alján fordulnak elő, mint pl. az egykori Ferencbánya helyén kialakult nagy tavas üregben. A karrmezők kis területi kiterjedése ellenére a sókőzet gyors oldódása miatt a formakincsük viszonylag változatos. A karrformák közül a lejtős területeken az áramlástól függő formák (rillek, rinnek) fordulnak elő a leggyakrabban, sík felszíneken madáritatók, a sófalakon falikarrok és vízszintes színlőszerű oldásos formák jellemzők. Utóbbiak a sós tó szintváltozásai során alakultak ki (Móga J. et al. 2015, 8. ábra).

\section{Küzdelmekkel teli jelen - bizonytalan jövő}

Az aknaszlatinai sóhegy az évszázadok óta tartó sóbányászat „tanúhegye”. Természeti és antropogén hatások során nyerte el mai formáját. Évszázadokon át bőséges forrása volt a kősónak, ami nem csak egy fontos nyersanyag, de éltető elem is. Ugyanakkor Aknaszlatina esete iskolapéldája annak, hogy a meggondolatlan, felelötlen emberi beavatkozás rövid idő alatt milyen drámai következményekkel jár a természeti környezetben, és hogyan válik veszélyforrássá az, ami erőforrás is lehetne.

A sókarsztos terület olyan, mint egy szabadtéri laboratórium. A sókőzetben és a sókőzeten lejátszódó folyamatok vizsgálata fontos a földtani-felszínalaktani eredetű veszélyforrások (geohazard) feltárásában és mintegy modellként szolgálnak a gyorsan 


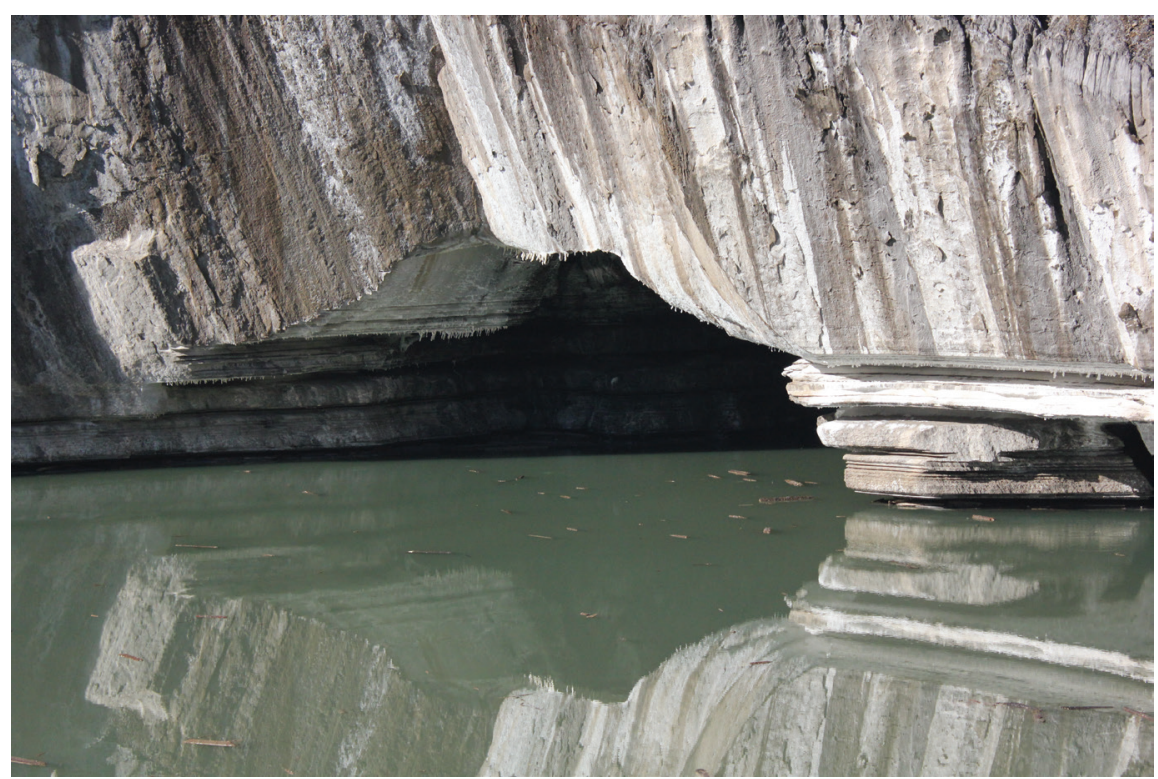

8. ábra. A Ferenc-bánya egyik vágata a szakadéktöbre alján (fotó: Móga J.)

lejátszódó természetes felszínformáló folyamatok megértéséhez. Másrészt a természetes hatásokra és emberi beavatkozásokra nagyon érzékeny sókarszt a meggondolatlan földhasználat, a nem megfelelő hasznosítás nyomán elszabaduló antropogén felszínformáló folyamatok iskolapéldája, ahol a káros hatások megismerése, megelőzése, megfékezése és a károk mérséklése napjaink fontos feladatai közé tartozik.

Évek óta követjük, illetve vizsgáljuk az Aknaszlatinán végbemenő, katasztrofális következményekkel járó változásokat, a sóbányák vízbetörések következtében lejátszódó beomlását és az épületek ezek hatásárára bekövetkező károsodását, pusztulását (9. ábra). Az egykori tíz bánya sok-sok km-nyi járatrendszere, amely még ma is behálózza a sódómot, mint egy időzített bomba ketyeg, szó szerint aláaknázva és veszélyeztetve a település házait. Nehéz megjósolni, hogy beomlásuk mikor és hol fog ismételten pusztulást okozni.

A sóbányák pusztulása súlyos társadalmi problémákat is eredményezett, hiszen megszünt a helybeliek megélhetését biztosító sókitermelés és - bár ebben más okok is szerepet játszottak - veszélybe került a sóterápiára alapozott gyógyturizmus. Geopolitikai kérdéssé vált a Felsö-Tisza-völgy legnagyobb magyar lélekszámú településének, Aknaszlatinának a fennmaradása. Stratégiai fontosságú kérdés a sóbányák 


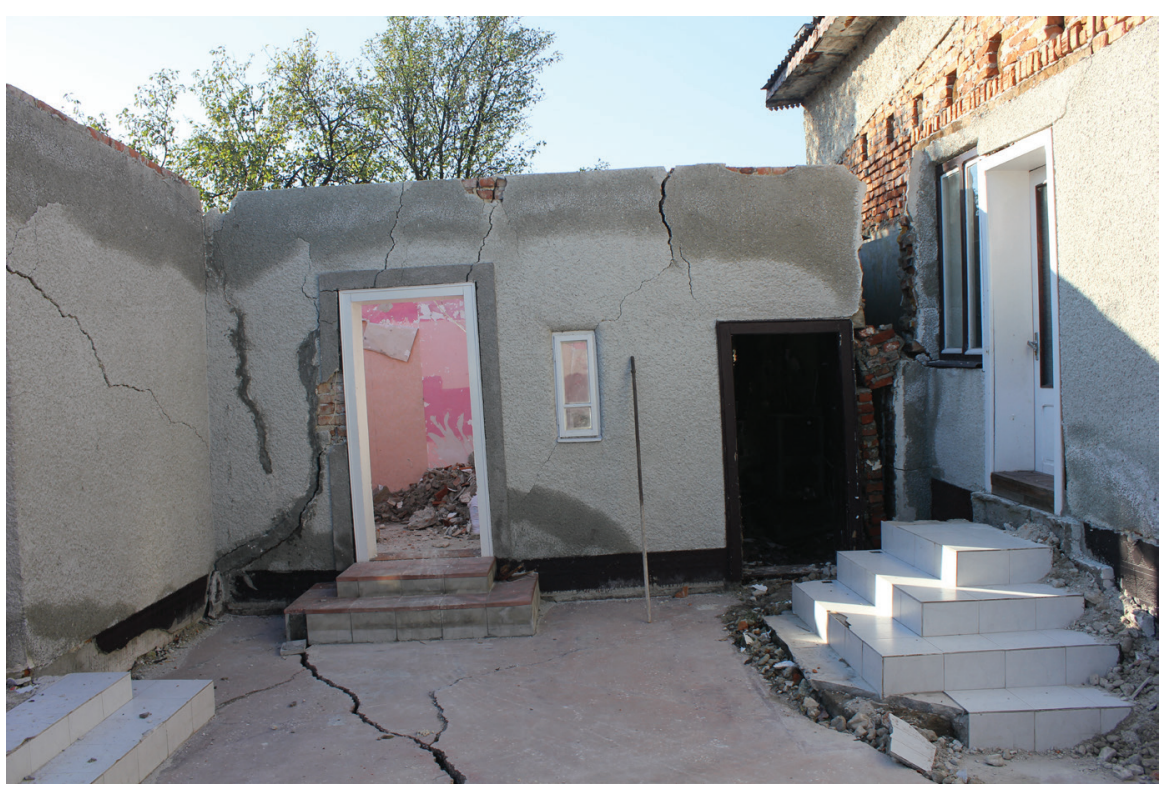

9. ábra. A Kilences-bánya beomlása miatt félig összedőlt épület Aknaszlatinán (fotó: Móga J.)

legalább mai környezeti állapotának konzerválása, megőrzése, a káros hatások megszüntetése. A sóhegy egyik nagy dolinatavába jelenleg tisztítás nélkül belefolyik Faluszlatina egy részének szennyvize, a szakadékok peremén a repedések további omlásokra figyelmeztetnek. A településen a szemétszállítás gyakorlatilag nem müködik, a lakosok egy része a szakadékokban kezdte felhalmozni háztartási hulladékát. Ezzel nemcsak testi épségüket veszélyeztetik a helyi lakosok, hanem tönkreteszik a jövőjüket is, beszenynyezik a csaknem százszázalékos tisztaságú sókészletet, amely megfelelö óvintézkedésekkel több száz évre biztosítani tudná a sókitermelést. Az évszázadok óta ott élő és mindmáig kitartó magyar kisebbséget nem hagyhatja magára a bajban az anyaország, meg kell találni a túléléshez vezető stratégiát. A sókarsztos rendszer működési folyamatainak megismerésével fontos lenne felmérni a várható káros következményeket, folyamatokat, amelyek segítséget nyújthatnak a nagy múltú sóbánya területén a további károk enyhítésében, megelözésében, az élhetö környezet kialakításában.

\section{Irodalom}

Berghauer S. 2012: A turizmus, mint kitörési pont Kárpátalján (?). Értékek, remények, lehetőségek Ukrajna legnyugatibb megyéjében. - Doktori $(\mathrm{PhD})$ értekezés. Pécsi Tudományegyetem Természettudományi Kar Földtudományok Doktori Iskola. Pécs. 213 p.

Cholnoky J. - Littke A. - Papp K. - Treitz P. 1926: A Föld. - A Műveltség Könyvtára. Athaenaeum, 
Budapest. 658 p.

ERDősI F. 1969: Az antropogén geomorfológia, mint új földrajzi tudományág. - Földrajzi Közlemények 17. 1. pp. 11-26.

ERDősı F. 1987: A társadalom hatása a felszínre, a vizekre és az éghajlatra a Mecsek tágabb környezetében. - Akadémiai Kiadó, Budapest. 227 p.

F. Romhányi B. 2016: A beregi egyezmény és a magyarországi sókereskedelem az Árpád-korban. - In: Kövér Gy. - PogÁny Á. - WeIsz B. (szerk.): Magyar Gazdaságtörténeti Évkönyv. Válság - kereskedelem. MTA Bölcsészettudományi Kutatóközpont. pp. 265-296.

Hahn Gy. 1993: A kősó szerepe Magyarország gazdaságtörténetében. - Földrajzi Értesítő 42. 1. pp. 15-22. Horváth G. - Móga J. - LeÉl Össy Sz. - ZÁmbó L. 2006: Karsztos tájak leromlása (degradációja) kínai karsztokon. - In: Kiss A. - Mezősi G. - Sümeghy Z. (szerk.): Táj, környezet és társadalom. Szegedi Tudományegyetem, Szeged. pp. 281-291.

Izsák T. 2007: Ukrajna természeti földrajza. - Rákóczi-füzetek 27. II. Rákóczi Ferenc Kárpátaljai Magyar Főiskola, Ungvár. 216 p.

JAKUCS L. 1971: A karsztok morfogenetikája. - Akadémia Kiadó, Budapest. 310 p.

LuKÁCs K. - LuKÁCs J. (1999): Aknaszlatina, a só, a víz és a levegő kincsestára. 117-173. pp. http://goo. gl/6OSjA 4

Móga J. - Lippman L. - Tombor E. - Fehér K. - Kéri A.- Borsodi A. 2015: Az Aknaszlatinai-sókarszt felszínalaktani vizsgálata. - Karsztfejlődés 20. Szombathely. pp. 185-213. DOI: 10.17701/15.185-213.

RÉTHy K. 2010: Aknaszlatina, az európai sóbányászat egyik fellegvára. - Bányászattörténeti Közlemények 9. (5.) 1. Rudabánya. pp. 42-48.

Schmidt Eligius R. 1941: A magyar só geológiája, bányászata és nemzetgazdasági jelentősége. - A Mérnöki Továbbképző Intézet 1941. évi tanfolyamainak anyaga 11. Budapest. 17 p.

Szokol P. 1879: Az akna-szlatinai sótelep bányászata. - Bányászati és Kohászati Lapok 12. 17-18. pp. 133-135. és 12. 19. pp. 148-149.

Veress M. 2004: A karszt. - Berzsenyi Dániel Főiskola Természetföldrajzi Tanszék. Szombathely. 215 p. Veress M. 2007: A magashegységi karrosodás. - Berzsenyi Dániel Főiskola Természetföldrajzi Tanszék. Szombathely. 142 p. 